\title{
Restrictive filling patterns in patients with reduced systolic left ventricular function: identification by velocity encoded magnetic resonance imaging
}

\author{
Kai Muellerleile ${ }^{1 *}$, Loant Baholli², Michael Groth¹, Achim Barmeyer², Gerhard Adam¹, Gunnar K Lund', \\ Thomas Rostock', Ulf K Radunski ${ }^{1}$, Ralf Koester ${ }^{1}$, Stephan Willems ${ }^{1}$
}

From 2011 SCMR/Euro CMR Joint Scientific Sessions

Nice, France. 3-6 February 2011

\section{Purpose}

To evaluate the ability of velocity encoded magnetic resonance imaging (VENC-MRI) to identify the presence of a restrictive filling pattern in patients with reduced systolic left ventricular (LV) function.

\section{Introduction}

A restrictive filling pattern is an independent prognostic marker for an increased mortality in patients with reduced systolic LV function. The diagnosis is currently established by characterization of transmitral and pulmonary-venous flow using Doppler-echocardiography. VENC-MRI enables robust quantification of transmitral as well as pulmonary-venous flow.

\section{Methods}

The study included 41 patients with reduced systolic LV function (ejection fraction $29 \pm 12 \%$ ). All patients underwent VENC-MRI and Doppler-echocardiography to assess the transmitral and pulmonary-venous flow characteristics. Figure 1 illustrates measurements of maximal early- and late-diastolic transmitral velocities ( $\mathrm{E}$ - and A-waves) as well as maximal systolic and diastolic pulmonary venous velocities ( $\mathrm{S}$ - and $\mathrm{D}$-wave). Restrictive filling pattern was defined by an E/A ratio $>2.0$ in combination with an S/D ratio < 1.0. Left atrial volume was obtained on long-axis cine-MRI slices using the biplane area-length method. N-terminal pro brain natriuretic peptide (NT-proBNP) levels were assessed as a marker

${ }^{1}$ University Medical Center Hamburg-Eppendorf, Hamburg, Germany Full list of author information is available at the end of the article for changed filling pressures. Maximal oxygen uptake (VO2-max) was assessed using spiroergometry.

\section{Results}

There was a very good correlation between VENC-MRI and Doppler-echocardiography for the $\mathrm{E} / \mathrm{A}$ ratio $(\mathrm{r}=0.86$, $\mathrm{P}<0.0001)$. The correlation was moderate between both methods for the $S / D$ ratio $(r=0.45, P<0.01)$. VENC-MRI identified 10 (24\%) and Doppler-echocardiography 7 (17\%) patients with restrictive filling pattern. The agreement between both methods was moderate (kappa= 0.49). Left atrial volumes were larger in patients with restrictive filling pattern than in patients without restrictive filling pattern $(143 \pm 41$ vs. $104 \pm 33 \mathrm{ml} ; \mathrm{P}<0.01)$. Higher NT-proBNP levels were found in patients with

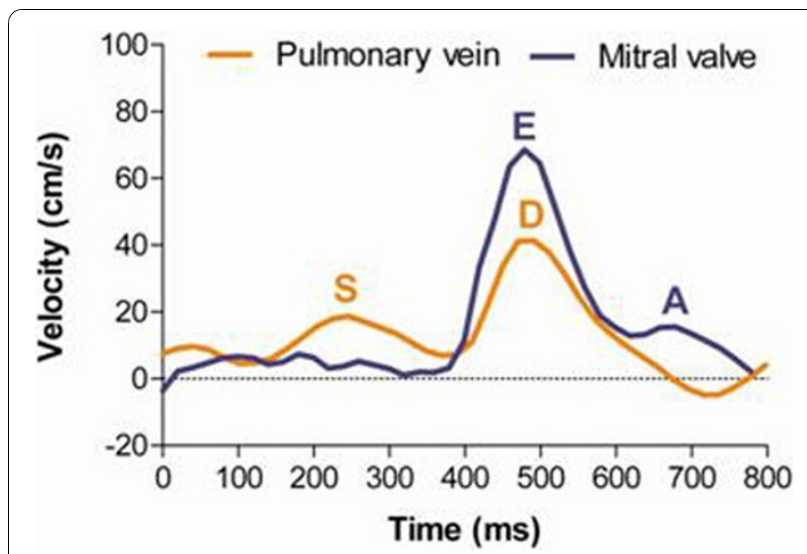

Figure 1 Transmitral and pulmonary venous flow characteristics by VENC-MRI. 
restrictive filling pattern compared to patients without restrictive filling pattern $(6090 \pm 7854$ vs. $1193 \pm 1387 \mathrm{ng} / \mathrm{l}$; $\mathrm{P}<0.01)$. VO2max was lower in patients with restrictive filling pattern compared to patients without restrictive filling pattern $(11.2 \pm 2.3$ vs. $14.2 \pm 4.8 \mathrm{ml} / \mathrm{min} / \mathrm{kg} ; \mathrm{P}=0.13)$

\section{Conclusions}

VENC-MRI has the ability to identify the presence of a restrictive filling pattern and may be a useful tool for the evaluation of patients with reduced systolic LV function.

\section{Author details}

${ }^{1}$ University Medical Center Hamburg-Eppendorf, Hamburg, Germany.

${ }^{2}$ Klinikum Dortmund, Dortmund, Germany.

Published: 2 February 2011

doi:10.1186/1532-429X-13-S1-P176

Cite this article as: Muellerleile et al:: Restrictive filling patterns in

patients with reduced systolic left ventricular function: identification by

velocity encoded magnetic resonance imaging. Journal of Cardiovascular

Magnetic Resonance 2011 13(Suppl 1):P176.

Submit your next manuscript to BioMed Central and take full advantage of:

- Convenient online submission

- Thorough peer review

- No space constraints or color figure charges

- Immediate publication on acceptance

- Inclusion in PubMed, CAS, Scopus and Google Scholar

- Research which is freely available for redistribution

Submit your manuscript at www.biomedcentral.com/submit 